\title{
John Howard: Storhed og Fald
}

Mads Qvortrup

\section{Den nu afgåede australske premierminister var hverken folkekær eller karismatisk - men dog for- måede han at vinde fire valgsejre og være ved magten i elleve år}

Jeg har kun mødt én enkelt australier, som syntes om John Howard. Han var en brugtvognsforhandler fra Toocwomba i delstaten Queensland.

Indrømmet, som gæsteprofessor ved universitetet i Sydney var undertegnede ikke just omgivet af partitro tilhængere af det Liberale Parti, som siden 1996 havde delt magten med det lille konservative parti The National Party. Men med bopæl i de såkaldte The Eastern Suburbs - Sydneys svar på Hellerup eller Gentofte - var jeg ej heller i et område med varme følelser for oppositionspartiet Labor.

John Howard var respekteret men ikke elsket. Han var kompetent, snu og kløgtig - men ikke charmerende. Den 24. november 2007 havde vælgerne i Australien fået nok. Over 53 procent af vælgerne stemte på Kevin Rudd - den tidlige- re karrierediplomat - der af medierne blev døbt Tintin.

John Howard havde overbevist sig selv og sit parti om, at man ikke taber valg, hvis økonomien er god, og hvis der er fred og ingen fare. Han tog fejl.

Det var en bet for den 68-årige John Winston Howard. Australiens 25. premierminister siden løsrivelsen fra Storbritanien i 1901 mistede ikke blot premierministerposten. Han tabte også sin valgkreds i Bennelong. Det er første gang siden premierminister Stanley Bruce i 1929 tabte sin valgkreds, at en siddende regeringschef ikke blev genvalgt til parlamentet i Canberra.

\section{Baronen fra benzintanken}

John Howards forgænger, socialdemokraten Paul Keating, kaldte ham 
en 'vinkelskriver fra forstæderne'. Det var ikke pænt ment. Men det var noget vælgerne syntes om. Den alt andet end karismatiske John Howard var først og fremmest en effektiv administrator - omend en populistisk sådan.

Fra sin opvækst på en benzintank i New South Wales var Howard en repræsentant for småborgerskabet. Det dyrkede han. Hans politiske helt var Sir Robert Menzies, grundlæggeren af det Liberale Parti og Australiens længst siddende premierminister.

I 1950'erne havde Menzies talt om 'det glemte folk' - the forgotten people. Hermed mente han de hårdt arbejdende - hvide - australiere. Det var også denne vælgergruppe John Howard appelerede til.

Med en blanding af fremmedfjensk retorik og økonomisk liberalisme gjorde Howard op med 1980' ernes socialdemokratiske regeringer. "Jeg ønsker at udvikle dette land fra en velfærdsstat til et mulighedernes samfund" sagde Howard under den nys overståede valgkamp. Det havde han på sæt og vis allerede gjort.

Skattesystemet var blevet ændret. Man indførte moms - i Australien kaldt Goods and Services Tax (ofte forkortet GST) - og sænkede indkomstskatten. Desuden indførte Howard i sin sidste valgperiode en række reformer af arbejdsmarkedslovgivningen der ophævede den kollektive forhandlingsret. Det sidste viste sig at koste ham dyrt.

\section{De fremmede}

Australien er et stort land med en lille befolkning. Det er geografisk på størrelse med USA, men befolkningstallet er ikke meget større end Hollands; knap 20 millioner.

Oprindeligt var befolkningen britisk. Mange var efterkommere af småkriminelle der var blevet sendt down under, da man i Victoria-tiden havde overfyldte fængsler i England.

Ud over disse var der mange englændere som frivilligt søgte nye muligheder i 'landet ved verdens ende' - som det blev kaldt.

At kontinentet allerede var befolket af aboriginals, var der få der tænkte på. I begyndelsen blev 'de vilde' accepteret, men det tog ikke lang tid før briterne begyndte et sandt folkedrab imod de indfødte. På øen Tasmanien - i Danmark kendt som Kronprinsessens fødeø gav briterne fem pund for hver $\mathrm{d} \varnothing \mathrm{d}$ aboriginal! Folkedrabet lykkedes. Tyskernes Endlösung mislykkedes. Englænderne var mere effektive! Men det hører vi ikke meget om i historietimerne. Sejrherren skriver historiebøgerne - og vi glemmer tit at briterne bag deres gentlemenidealer var rå og grusomme.

At vi på dette sted udbreder os om det britiske imperiums synder er ikke tilfældigt. Som efterkommere af den britiske indvandrere føler nogle hvide australiere, at de metaforisk set har blod på hænderne.

Det var en opfattelse der var ud- 


\section{MADS QVORTRUP}

bredt i mere progressive kredse. Man i den lavere middelklasse og den øverste del af arbejderklassen har der i de seneste mange år været irritation over den evindelige snak om kollektiv skyld.

I midten af 1990'erne - kort efter John Howard var kommet til magten - kom dette emne på dagsordenen, da Pauline Hanson - en tidligere servitrice fra en grillbar i Queensland - oprettede partiet One Nation. Partiet krævede et stop for indvandring fra Kina og andre asiatiske lande - samt et opgør med det man kaldte 'aboriginal-industrien'.

Ligesom Socialdemokratiet i Danmark har haft svært ved at finde deres ben i indvandringsspørgsmålet, var også det australske Labor i vildrede. Det benyttede John Howard sig af. Ved at gentage Pauline Hansons retorik - omend uden at gennemføre mere end symbolske dele af hendes program - formåede Howard at pacificere den populistiske højrefløj samtidigt med, at han kunne hente stemmer fra arbejderklassen.

Lidt ligesom i England hvor Margaret Thatcher scorede stemmer fra faglærte arbejdere som tidligere havde stemt på Labour, høstede Howard stemmer blandt de såkaldte 'Howard battlers', dvs. personer med lavere uddannelse og små lønninger som tidligere havde stemt på Labor.

Men denne iver efter at tækkes folkestemningen betød ikke kun, at
Howard gennemførte højrefløjens mærkesager. Da en galning i 1996 gik amok med et maskingevær i Port Arthur på Tasmanien og dræbte en halv snes uskyldige mennesker, greb Howard resolut ind og forbød de fleste skydevåben - og det til trods for, at våbenlobbyen er stærk i Australien - og en bidragyder til koalitionspartneren The Nationals. Men denne populisme fortog sig gradvist, efterhånden som Howard følte sig mere sikker på sin position.

Med en stigende multikulturel befolkning - og indvandring fra Asien - blev det sværere for Howard at fastholde idealet om Australien som et 'lille stykke England' i Stillehavet.

Nok lykkedes det Howard - med nød og næppe - at undgå, at man ophævede monarkiet (Dronning Elizabeth er stadig det officielle statsoverhoved). Men der var en følelse af, at man levede på lånt tid.

\section{USA}

Howard er givetvis den mest proamerikanske premierminister $\mathrm{Au}-$ stralien har haft siden midten af 1960'erne. Forholdet til USA har altid været en kilde til utilfredshed i befolkningen. Det skyldtes ikke mindst, at regeringerne i 1960'erne blev tvunget til at gå med i Vietnamkrigen. Daværende premierminister Harold Holt erklærede på sit lands vegne "we will go all the way with LBJ" (forbogstaverne for den daværende amerikanske præsident 
Lyndon B. Johnson). Det var ikke populært dengang. Der døde mange australske værnepligtige i Vietnam.

Det var heller ikke populært, at John Howard entydigt accepterede at sende tropper til Irak. Men - lidt ligesom Anders Fogh Rasmussen i Danmark - var Howard ubøjelig i sin støtte til supermagten.

Det ville under normale omstændigheder have ført til vælgermæsig utilfredshed. Men til held for Howard var oppositionen - lidt ligesom i Danmark på samme tid - splittet, rådvild og $\mathrm{i}$ vildrede. Den situation $\mathrm{i}$ Australien var unik.

\section{Latham og de andre}

Man havde sjældent set noget lignende. Selv ikke i Australien hvor der er væsentligt mere frisprog end andre steder i den vestlige verden.

Den tidligere Labor-leder Mark Latham var nok kendt som en farverig personlighed med et blomstrende sprog. Men alligevel. Han havde tidligere kaldt John Howard en 'arselicker' - direkte oversat en 'røvslikker'. Men hans dagbøger var om muligt endnu mere uhøviske. I efteråret 2005 var selv garvede politiske skribenter mundlammme.

The Latham Diaries - Lathams Dagbøger - indeholdt karaktermord efter karaktermord på den tidligere oppositionsleders partifæller. Hvis man ønsker et overblik over australske bandeord kan man passende be- gynde her! Labor forsøgte at ignorere den - tilsyneladende paranoide forhenværende partileder. Men i offentligheden blev partiet opfattet som uregerbart og splittet.

Efter valgnederlaget i $2005 \mathrm{var}$ Latham trådt tilbage. Han kunne dårligt gøre andet. Regeringen vandt et flertal i begge parlamentets kamre for første gang siden 1959. Og det gjorde den ved at offentliggøre materiale om Lathams alt andet end blanke straffeattest.

Ud over at have banket sin tidligere kone og brækket armen på en taxachauffør, havde Latham været borgmester i provinsbyen Liverpool, da den gik fallit. Det var ikke noget positivt skudsmål for en mand, der var op imod en regering der - med rette eller urette - tog æren for den længste vækstperiode i historien.

To år inden valget var der ingen der troede på Labor. Efter Lathams afgang havde man valgt Kim Beazeley - en trivelig historielektor fra Western Australia - der to gange tidligere havde tabt parlamentsvalg til John Howard.

At man valgte en taber kunne virke overraskende. Men Australien er lidt anderledes. I de fleste lande får man kun én chance for at vinde magten. Men det er ikke tilfældet i Australien. John Howard havde været partileder to gange tidligere, da han vandt valget i 1996. (Han beskrev sig selv som Lazarus).

Men Beazeley var - og er - ikke John Howard. Ingen gav ham nogen 


\section{MADS QVORTRUP}

chancer. Alt tydede på, at Howard ville vinde igen. Det ændrede sig med et i december 2006. Stik mod al forventning udfordrede Labors udenrigspolitiske ordfører Kevin Rudd den siddende formand. $\mathrm{Og}$ stik mod al forventning blev Beazeley væltet.

\section{Lykken vender}

Og pludselig begyndte alting for alvor at gå galt for Howard. Under valgkampen i 2005 havde premierministeren lovet, at der ikke ville blive rentestigninger. Men regeringens ekspansive finanspolitik medførte stigende forbrug. For at hindre inflation hævede nationalbanken renten. Det skete seks gange.

Vælgere der havde købt hus kunne mærke, at de pludselig havde væsentligt mindre økonmisk råderum. De havde aldrig elsket John Howard. Hans lidt kontrære gemyt var ikke just folkekært, men han havde været accepteret som en kyndig kassemester.

Med den begyndende økonomiske krise vendte de ham ryggen.

En politisk ulykke kommer sjældent alene. Miljøpolitiken blev også et omdiskuteret emne. John Howard var ikke en mand der læste bøger. Selvom han påstod, at han som barn havde læst Karl Marx! Igennem hele sin regeringsperiode henviste han kun til én bog. Det var Bjørn Lomborgs The Sceptical Environmentalist.
Ligesom George Bush - og tidligere Anders Fogh Rasmussen - var Howard skeptisk over for den megen snak om klimaforandringer. Han argumenterede længe for, at drivhuseffekten var en myte.

Det har de fleste australiere det godt med. Men den lange tørkeperiode siden sidste valg - den værste $\mathrm{i}$ 100 år - førte til, at mange begyndte at spørge, om der kunne være en sammenhæng mellem vejret og det stigende energiforbrug.

Howard nægtede at det var tilfældet. I lighed med USA's regering afslog han - trods bønner fra miljøminister Malcolm Turnbull - at ratificere Kyoto-aftalen.

Men hvor miljøpolitiken tidligere havde været et marginalt emne, var det pludseligt blevet et politisk hovedspørgsmål. Meningsmålingerne viste, at vælgerne gav Howards regering skylden for tørken og forureningen.

Alt dette førte til, at koalitionsregeringen i begyndelsen af 2007 var elleve procent bagud i meningsmålingerne. Det skabte uro blandt de menige parlamentsmedlemmer.

John Howard havde gennem hele sin regeringsperiode haft et anspændt forhold til finansminister Peter Costello. Denne følte sig forbigået - og pønsede konstant på at overtage magten i partiet.

Situationen var på den måde lidt a la i Storbritannien hvor Tony Blair havde lovet Gordon Brown, at han skulle efterfølge ham. Der eksistere- 
de en tilsvarende aftale mellem Howard og Costello. Men detaljerne var uklare - og Howard mente ikke, at de dårlige meningsmålinger havde den store betydning.

Det havde han god grund til at tro. Inden valgene i 2001 og 2004 havde koalitionen også været bagud i meningsmålingerne, men havde overhalet oppositionen i de sidste måneder inden valget.

Men denne gang så det ikke ud til at være tilfældet. I efteråret - foråret på den sydlige halvkugle - var meningsmålingerne stadig i Labors favør.

Det skabte panik i det Liberale Parti - samt hos deres koalitionspartner. Man forsøgte sig med dirty tricks.

Under et besøg i New York havde oppositionslederen Kevin Rudd besøgt en strip-bar. Det var pinligt for den regelrette tidligere diplomat, der ud over at være lykkeligt gift også var en trofast kirkegænger.

Ligesom man ved valget i 2004 havde formået at tilsmæde Mark Latham, forsøgte de Liberale nu at gentage successen med Kevin Rudd. Det mislykkedes totalt. Rudd udstedte straks en mea culpa-sagde undskyld til sin kone. Og så var den sag ude af verden. Troede man da. For i realiteten styrkede den oppositionslederen.

Rudd der var blevet opfattet som en halvkedelig nørd, fik pludselig respekt blandt australake mænd. Ikke overraskende måske; en stati- stik viste at 95 procent af alle mænd i Australien havde besøgt en såkaldt 'gentlemens club'. De Liberale derimod blev udstillet som moraliserende.

Disse problemer førte til, at Costello - og især hans tilhængere begyndte at bagtale John Howard. Borgerkrigen i regeringen resulterede $\mathrm{i}$, at John Howard på et ministermøde bad sine kolleger om et tillidsvotum. Det fik han ikke! Men han fortsatte alligevel. En siddende premierminister kan kun afsættes af hele parlamentsgruppen.

Men nederlaget i tillidsafstemningen havde den konsekvens, at Howard erklærede, at han ville overdrage magten til Costello efter valget.

\section{Valg}

Valget blev udskrevet i oktober. De Liberale var stadig bagud. Men som i tidligere valgkampe havde de en trumf i ærmet. På valgkampens første dag offentliggjorde de planer om øgede udgifter til pensionister og børnefamilier.

Disse forslag blev matchet af Labor - omend til en billigere pris.

Det sidste var væsentligt. Labors skyggefinansminister Wayne Swan Kevin Rudds barndomsven (de gik på samme gymnasium) sagde, at regeringens forslag ville føre til inflation. Det blev afvist af Peter Costello og John Howard.

Men regeringen kontrollerer ikke pengepolitikken. Nationalbanken 


\section{MADS QVORTRUP}

greb ind og hævede endnu engang renten. John Howard havde svært ved at finde en grimasse, der kunne passe på den pinible situation.

Gennem hele valgkampen forsøgte regeringen at føre en skræmmekampagne. De kritiserede Labor for at være utroværdige og for at ville føre Australien tilbage til tidligere tiders overbudspolitik. Men det var vanskeligt at anklage oppositionen herfor, når nationalbanken havde kritiseret regeringen for deres lempelige finanspolitik.

Man prøvede igen med personlige angreb på Kevin Rudd. Men det var svært at finde belastende materiale om ham. Man forsøgte at spille på hans manglende ministererfaring og hans mangel på internationale kontakter. Det tilbageviste Rudd i handling mere end i ord.

Ved stillehavslandenes topmøde i organisationen APEC i Sydney i september gik Rudd op til den kinesiske delegation og begyndte at tale med dem om handelsforbindelser. Men han talte ikke engelsk - men derimod kinesisk. Repræsentanterne fra Australiens væsentligste handelspartner var imponerede. Howard der kun taler engelsk surmulede.

At Rudd - der har en universitetsgrad i kinesisk - kunne konversere med repræsentanterne fra Bejing var ikke kun populært i den kinesiske hovedstad. Det gav ham også støtte blandt den store - og voksende - gruppe af kinesiske immigran- ter i Sydney. Disse havde tidligere stemt på Howard. De skiftede nu parti.

Mens mest vigtigt. I modsætning til tidligere var Rupert Murdochs medie-imperium bag Rudd. Vennerne havde vendt Howard ryggen.

\section{Resultatet}

Det var en fattet John Howard der mødte sine tilhængere tidligt på valgaftenen. Labor skulle vinde 16 pladser i parlamentet. De vandt 24. Og et af dem var i Bennelong. Labor havde vundet kredsen.

Men sejren var ikke total. Nok vandt Labor et flertal i Underhuset. Men da kun halvdelen af pladserne i Overhuset var på valg, havde de ikke et flertal i begge kamre. Det ville under normale forhold have skabt problemer. Men ikke denne gang. Oppositionspartiet accepterede, at nederlaget gav Labor et mandat til at gennemføre forandringer.

På sin første arbejdsdag 1. december 2007 underskrev Rudd Kyoto-aftalen, og senere samme dag mødtes han med repræsenanter for forsvarsministeriet for at tale om tilbagetrækningen af tropper fra Irak.

På det tidspunkt var det Liberale Parti internt splittet. Peter Costello have overraskende trukket sig. Partiet havde istedet valgt Brendan Nelson - en tidligere formand for lægeforeningen - som ny partiformand. Men ingen i partiet så fremad tværtimod var det $\mathrm{i}$ åben strid om 
hvem, der var skyld i nederlaget.

Men trods den splittede opposition så situationen alt andet end lys ud for Kevin Rudd og hans finansminister Wayne Swan. Økonomer advarede om lav-konjunktur. Swans første embedshandling var at advare om nedskæringer i den offentlige sektor.

Ligesom i 1970'erne hvor Labors Geoff Whitlam vandt magten efter en periode med konservative regeringers overforbrug og militære eventyr, er Rudd i den samme situation. John Howard kom til efter en periode af reformer under Labor og kunne senere tage æren. Nu er det igen Labors tur til at rydde op. Det bliver ikke let.

Mads Qvortrup er professor i statskundskab ved Robert Gordon University $i$ Skotland og har tidligere veret gesteprofessor ved University of Sydney 